\title{
Wistar Rat Weight Loss on Conventional Cigarette Exposure Compared to E-Cigarette
}

\author{
Cakrawati Hanna, Nurpangestu Budian
}

\begin{abstract}
Several studies have shown that smoking behavior is closely related to weight and obesity. Smokers tend to prefer fatty foods with high calories which ultimately makes a smoker vulnerable to being overweight. However, there are some studies that show lower body weight was found in smokers than nonsmokers. Our aim is to evaluate the short-term effects of smoking with conventional cigarettes and e-cigarret on weight changes in Wistar rats because animals try to minimize some confounding factors that are difficult to work on human samples (for example, physical activity, diet and motivation). This research is an experimental study, using 8-week-old male Wistar rats with body weight 150-200 grams divided randomly into 5 groups, namely 1) the group was not treated, 2) the filter cigarette exposure group, 3) the clove cigarette group, 4) e-cigarette group with a dose of $3 \mathrm{~mL}$ with nicotine content of $0 \mathrm{mg}$, and 5) $e$ cigarette group with a dose of $3 \mathrm{~mL}$ with nicotine content of 3 mg. Body weight measurements using a digital scale. The results showed that there was a significant change in body weight between clove cigarettes and filter cigarettes with $p=0.024$. In the results of this study, showed weight loss in all groups given cigarette smoke. Weight loss was significantly lower in the filter cigarette group compared to clove cigarettes and there was no significant weight difference between the conventional cigarette group and e-cigarette. This is likely the cigarette filter actually creates a major problem for smokers because of the design and materials used so it does not provide a safer effect for smoker.
\end{abstract}

Keywords: Cigarette, E-cigarette, Filter cigarettes, Nicotine, Weight

\section{INTRODUCTION}

Smoking is a major public health problem throughout the world [1]. Meanwhile, according to the Southeast Asia Tobacco Control Alliance (SEATCA) report titled The Tobacco Control Atlas, this data adds to Indonesia as the highest number of smokers in ASEAN, which is 65.19 million people. This figure is equivalent to $34 \%$ of the total population of Indonesia in 2016 [2]. Smoking and nicotine exposure are associated with premature death due to the public health burden, economic losses to society, and chronic illness.

According to research conducted by Chiolero Arnaud, the finding of obesity risk increases along with the large number of cigarettes smoked every day [3]. There is a positive relationship between the number of cigarettes smoked and an increase in BMI. Research on the group of women for 8 years showed that the nonsmoking group had a lower body than smokers or smokers. Smokers with the category of

Revised Manuscript Received on January 2, 2020.

* Correspondence Author

Cakrawati Hanna, department of physiology, Muhammadiyah University Of Malang, Malang City, Indonesia. Email: hanna.bdz@gmail.com

Nurpangestu Budian, Medical School, Muhammadiyah University Of Malang, Malang City, Indonesia. Email: budian_np@yahoo.com heavy smokers have a body weight that continues to increase than the category of light smokers in that group [3]. A cross-sectional study shows if heavy smokers (2 packs / day) can be associated with an increased risk of greater obesity. In the Cancer Prevention Study found heavy smokers (40 cigarettes / day) were more likely to have a heavier weight compared to light smokers (1-20 cigarettes / day) and moderate smokers (20-40 cigarettes / day) [4]. In a large survey in the adult population in Switzerland, that obesity is increasing with smoking. In the sample of heavy smokers (20 cigarettes/day) have a higher excess weight compared to moderate smokers (10-19 cigarettes/day) and mild smokers (1-9 cigarettes/day). These findings indicate that smoking has a positive relationship with body weight and heavy smokers have increased body weight or excess light smokers [5]. This is likely in heavy smokers to be more likely to have behaviors that can encourage weight gain (eg unhealthy diets, low physical activity and high alcohol intake) than nonsmokers or mild smokers. But several other studies actually found the opposite. Many cross-sectional studies have shown that body weight, or body mass index (BMI; in $\mathrm{kg} / \mathrm{m} 2$ ), is lower in smokers than in nonsmokers. Smoking a cigarette containing $0.8 \mathrm{mg}$ of nicotine has been shown to cause a $3 \%$ increase in resting energy expenditure (REE) within 30 minutes and the possibility of sympathetic stimulation in the nervous system [6]. REE is energy expenditure for people who are lying down who are not fasting and is the amount of Basal Energy Expenditure (BEE or also better known as BMR) and dietary induced thermogenesis (DIT or better known as specific dynamic action (SDA)).

\section{MATERIALS AND METHODS}

\section{A. Research Subjects}

This research is an experimental study, using 8-week-old male Wistar rats with a body weight of 150-200 grams, healthy, active and good appetite. Mice that were not included in this study were mice that were sick, less active or lazy to move and mice died during the treatment period. Rats were divided into 5 groups, namely 1 ) the group was not treated as a negative control group, 2) the filter cigarette group, 3) the clove cigarette group, 4) the e-cigarette group with a dose of $3 \mathrm{~mL}$ with nicotine levels $0 \mathrm{mg}$, and 5) the group e-cigarette at a dose of $3 \mathrm{~mL}$ with nicotine levels of 3 $\mathrm{mg}$. The sample size used is determined using the formula DF (Degrees of freedom), based on the minimum and maximum vulnerable values, the total sample of this study is 15-25 samples. 
Where the number of samples used a total of 25 samples divided into 5 treatment groups with each treatment group filled by 3 male white rats (Rattus norvegicus strain wistar). The technique for sampling uses Simple Random Sampling from rat populations.

\section{B. Research Procedures}

Mice will be exposed to conventional cigarette smoke and ecigarettes every day for 30 days in a smoking box. Before being given treatment, the rats were first adapted for 7 days. Rats get free access to take food and drink. Optimum temperature observations for experimental animals and animal house ventilation are considered. Mice are also introduced to the smoking box by occupying and allowing the mice to adapt in the box within a few minutes each day to minimize stress during treatment. Measurement of body weight of rats using digital scales and measured every morning on the first day, 7th day, 14th day, 21th day, 30th day and 37 th day.

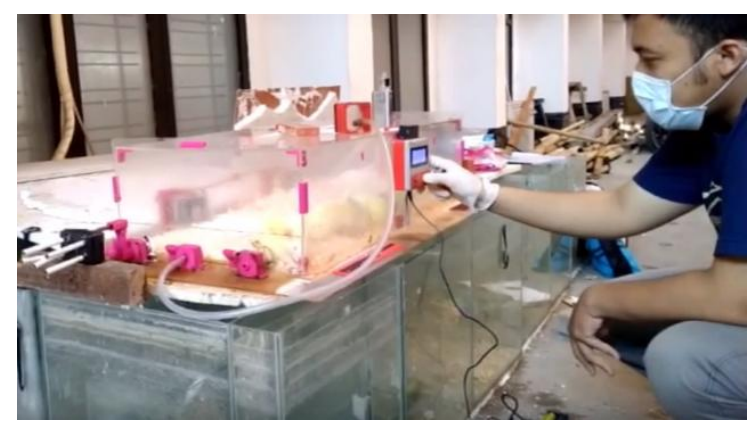

Fig. 1.Exposure to cigarette smoke using a smoking box

\section{RESULTS AND DISCUSSION}

The results of the study in the form of calculating the average weight of Wistar rats in each group are shown in figure. 2 below.

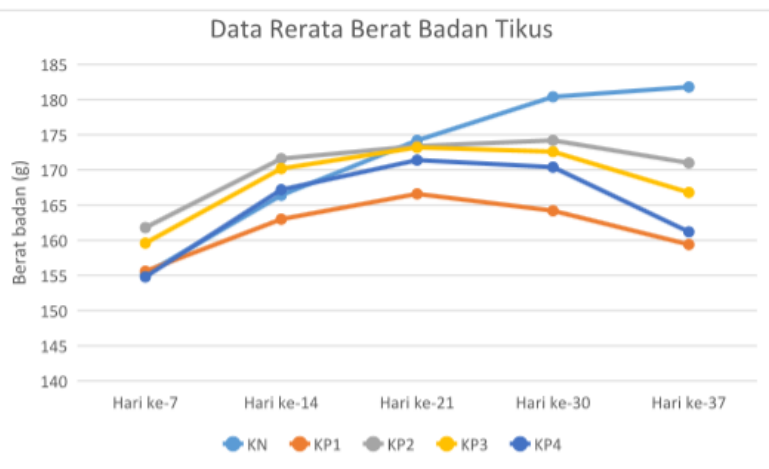

Fig. 2.Graph of Average Mouse Weight. KN: group of mice that were not given treatment; KP1: filter cigarette mouse group; KP2: cretrek cigarette rat group; KP3: nicotine 0mg e-ciggaret mouse group; KP4: nicotine nicotine $3 \mathrm{mg}$ rat group

Figure. 2 shows a decrease in body weight in all treatment groups when compared to the group of mice that did not get treatment. The lowest weight loss was found in the group of mice that were exposed to filtered cigarette smoke.
Table-I: Post Hoc Analysis

\begin{tabular}{l|l|l}
\hline Treatment group (I) & Treatment group (II) & Sig. \\
\hline \multirow{4}{*}{ Negative control (K-) } & Cigarette Filter & .766 \\
\cline { 2 - 3 } & Clove & 1.000 \\
\cline { 2 - 3 } & E-cigarette 0mg & 1.000 \\
\cline { 2 - 3 } & E-cigarette 3mg & 1.000 \\
\hline \multirow{4}{*}{ Clove Cigarette } & K- & 1.000 \\
\cline { 2 - 3 } & Cigarette Filter & .033 \\
\hline
\end{tabular}

In the Post Hoc analysis (table-I), the results showed a significant difference in body weight with a value $(\mathrm{p}=0.033)$ where the value $(\mathrm{p}<0.05)$, between the clove cigarette treatment group and filter cigarettes. The body weight of rats exposed to clove cigarettes has a slightly heavier weight compared to the filter cigarette group

There are two types of cigarette products in Indonesia, namely white cigarettes (ie filtered cigarettes at the end made of cork that function as filters for cigarette smoke) outside Indonesia better known as cigarrets and clove cigarettes (ie cigarettes that do not have filters at the ends) are known as clove cigarettes are cigarettes made from tobacco, cloves, clove oil, and other additives. White cigarettes are well known throughout the world, but clove cigarettes are a unique production from Indonesia [7]. The Food and Drug Supervisory Agency (BPOM) states that the highest nicotine content in cigarettes circulating in Indonesia is currently $4 \mathrm{mg}$ found in hand-rolled kretek cigarettes. While the nicotine content that is most commonly found in the Indonesian market is $25.5 \mathrm{mg}$ for kretek cigarettes using a machine [8].

E-cigarret or better known as vape is an electrical device for smoking that uses liquid containing nicotine and other substances that are heated to create aerosols. This cigarette is still quite new and has become a lifestyle nowadays both in adolescents and adults. The American Cancer Society found 22 toxic substances other than nicotine reported in cartridge fluids and emissions and still need to be examined for long-term [9].

In our results, it showed that there was a decrease in body weight of rats in all treatment groups that had been given exposure to cigarette smoke when compared with control mice that were not treated tended to show weight gain even though statistically showed no significant difference in body weight. The occurrence of weight loss like this shows that nicotine is known as a major addictive component apart from cadmium, tar, carbon monoxide and carbon dioxide which can be found in tobacco burning smoke can increase the release of dopamine neurotransmitters in the brain's reward center and create a sensation of pleasure. Nicotine shows anorexigenic nature (loss of appetite) and is one of the causes of weight loss in rats exposed to cigarettes. The area of the brain responsible for playing a role as modulating energy balance is the hypothalamus. The regulation of food intake behavior is based on satiety signals stopping food intake by inhibiting the center eating and hunger signals that make you want to eat by inhibiting the center of satiety. 
Activation of hypothalamic AMP by nicotine induction will cause weight loss, decreased orexigenic signals in the hypothalamus, increased thermogenesis in brown adipose tissue (BAT), changes in fuel use and increased energy caused by increased use of locomotor. Recent studies in mice will show that nicotine induction will activate melanocortin-4 receptor (MC4R) in hypothalamic proopiomelanocortin (POMC) neurons which can hold off appetite and increase satiety [10]. Nicotine can also activate nAChR (Nicotinic acetylcholine receptors) in the adrenal medulla causing increased catecholamine release and an impact on an increased metabolic response (increasing the release of free fatty acids and blood glucose as well as mobilizing carbohydrate and fat energy) and cardiovascular (increasing pulse rate and blood pressure) [11].

In this study also found a significant decrease in body weight was lower in the filter cigarette group compared to clove cigarettes and there was no significant weight difference between the conventional cigarette group and eciggaret. When comparing the nicotine content in each cigarette listed on the cigarette pack. Clove cigarettes have nicotine content bigger than filter cigarettes. In a study conducted by Susanna D, Hartono B, and Fauzan H (2003), from the measurement of nicotine levels using high performance liquid chromatography (High Performance Liquid Chromatography) conducted on two types of cigarettes, it was concluded that the highest nicotine levels were obtained in clove cigarettes compared to fiter cigarettes [12]. Filter materials in cigarettes (made from cellulose acetate and charcoal fiber) and filter designs (ventilation filters and multi-segment filters) that have been widely circulated in filtered cigarettes are believed to reduce some of the most dangerous substances in cigarette smoke such as cadmium, tar, nicotine carbon monoxide and carbon dioxide [13].

But some research found that the cigarette filter design (ventilation filter) actually gives smokers higher yields than expected from the standard machine smoke test (Federal Trade Commission (FTC), namely International Organization for Standardization (ISO) [14]. They concluded if the ventilation filter is a dangerous technology and defects that must be abandoned. Ventilation filters create a major problem by misleading consumers to feel that cigarettes have a lighter and lighter nicotine content so that they appear to be less harmful to smokers.

\section{CONCLUSION}

This study showed a decrease in body weight in all groups giving cigarette smoke. Weight loss was significantly lower in the filter cigarette group compared to clove cigarettes and there was no significant weight difference between the conventional cigarette group and e-cigarette. This is likely the cigarette filter actually creates a major problem for smokers because of the design and materials used so it does not provide a safer effect for smokers.

\section{REFERENCES}

1. Tweed JO, Hsia HS, Lutfy K and Friedman TC, 2012. The endocrine effects of nicotine and cigarette smoke. Trends Endocrinol Metab. Vol 23(7):pp. 334-342
2. Widowati Hari, 2019. Indonesia, Negara dengan Jumlah Perokok Terbanyak di Asean. Katadata.co.id

3. Chiolero Arnaud, Faeh David, Paccaud Fred, and Cornuz Jacques, 2008. Consequences of smoking for body weight, body fat distribution, and insulin resistance. Am J Clin Nutr. Vol 87: pp: 801-9

4. Rasky E, Stronegger WJ , Freidl W, 1996.The Relationship between BodyWeight and Patterns of Smoking in Women and Men. International Journal of Epidemiology, Vol 25 (6); pp: 1208-11

5. Eliasson B, 2003. Cigarette smoking and diabetes. Progress in Cardiovascular Diseases, vol 45(5), 405-413

6. Chiolero A, Faeh D, Paccaud F, \& Cornuz J, 2008. Consequences of smoking for body weight, body fat distribution, and insulin resistance. The American Journal of Clinical Nutrition, 87(4), 801-809

7. Newman Barry, 2009.To the FDA, This Indonesian Smoke Is Close but No Cigar With Ban on Clove Cigarettes, Importer Claims Its Product Is All Stogie. WSJ. Available at https://www.wsj.com/articles/SB125660066262509223

8. Juniman PT, 2018. Hari Tanpa Tembakau Sedunia Kadar Maksimal Nikotin dalam Rokok di Indonesia Masih Tinggi. CNN Indonesia. Available at https://www.cnnindonesia.com/gayahidup/20180531204622-255-302668/kadar-maksimal-nikotin-dalamrokok-di-indonesia-masih-tinggi

9. Rehan HS, Maini J, Hungin APS, 2018. Vaping versus Smoking: A Quest for Efficacy and Safety of E-cigarette. Curr Drug Saf. 13(2):92101

10. Martínez de Morentin PB, Whittle AJ, Fernø J, Nogueiras R, Diéguez C, Vidal-Puig Antonio, Lópezi M, 2012. Nicotine Induces Negative Energy Balance Through Hypothalamic AMP-Activated Protein Kinase. Diabetes, Vol.61: pp 807-817

11. Benowitz Neal L, 2009. Pharmacology of Nicotine: Addiction, Smoking-Induced Disease,and Therapeutics. Annu Rev Pharmacol Toxicol. Vol 49: pp: 57-71

12. Susanna Dewi, Hartono Budi, dan Fauzan Hendra, 2003. Penentuan Kadar Nikotin Dalam Asap Rokok. MAKARA Kesehatan, Vol. 7 (2). Available at https://media.neliti.com/media/publications/83565-IDpenentuan-kadar-nikotin-dalam-asap-rokok.pdf

13. Pauly JL, O’Connor RJ, Paszkiewicz GM, Cummings KM, Djordjevic MV \& Shields PG, 2009. Cigarette Filter-based Assays as Proxies for Toxicant Exposure and Smoking Behavior--A Literature Review. Cancer Epidemiology Biomarkers \& Prevention, 18(12), 3321-3333

14. Kozlowski LT, \& O'Connor RJ, 2002. Cigarette filter ventilation is defective design because of misleading taste, bigger puffs, and blocked vents. Tobacco Control, Vol.11(Supplement 1); pp: i40-i50

15. Russell MA, Jarvis M, Iyer R, \& Feyerabend C. (1980). Relation of nicotine yield of cigarettes to blood nicotine concentrations in smokers. BMJ, 280(6219), 972-976

\section{AUTHORS PROFILE}

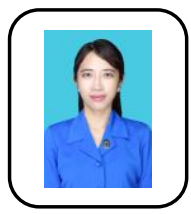

Hanna Cakrawati, is a teaching lecturer in the faculty of physiology, faculty of medicine, Malang Muhammadiyah University. She is a graduate of medicine and a biomedical masters degree. Where she conducted research in the broad field of sports physiology. she has around 3 research publications papers and is currently conducting further research on sports and cigarette discussions

Budian Nurpangestu, is a medical student from Malang Muhammadiyah University who is very interested in reading references and research on the effects of electronic cigarettes. 